\title{
Perennial Iupin establishment and yield when sown at five different rates at Glenmore Station, Lake Tekapo.
}

\author{
D.J. MOOT and K.M. POLLOCK \\ Faculty of Agriculture and Life Sciences, PO Box 85804, \\ Lincoln University, Lincoln 7647, Christchurch, New Zealand
}

Derrick.Moot@lincoln.ac.nz

\begin{abstract}
The potential for perennial lupins to underpin grass/ legume pastures was the subject of a research programme for merino farmers in areas where more conventional legumes struggle to thrive. A previously uncultivated pasture on an acidic soil, $(\mathrm{pH} 5.0 ; \mathrm{Al}=$ $5 \mathrm{mg} / \mathrm{kg}$ ), and dominated by browntop, sweet vernal and Kentucky bluegrass, was sprayed with herbicide, burnt and top-dressed with $3 \mathrm{t} / \mathrm{ha}$ lime on half the area in the autumn prior to direct drilling on 12 Dec 2012. A blue perennial lupin and a multi-coloured (Russell) lupin were sown at 2, 4, 8, 12, 16 and $32 \mathrm{~kg} / \mathrm{ha}$ and cocksfoot at $2 \mathrm{~kg} / \mathrm{ha}$. Yield at four months after sowing had increased with the lupin sowing rate; up to $5.5 \mathrm{t}$ dry matter (DM)/ha at $32 \mathrm{~kg} \mathrm{seed} / \mathrm{ha}$. The annual yield for the following growth season was greater than $10 \mathrm{tDM} /$ ha with little response above $8 \mathrm{~kg}$ lupin seed/ha. There was a small but inconsistent response to the lime by the Russell lupin. Overall, lupin contributed $79 \%$ of annual yield and $>90 \%$ of the spring yield at sowing rates $>8$ $\mathrm{kg} / \mathrm{ha}$. The sown cocksfoot and resident grasses showed a positive lime response at the lower lupin sowing rates.
\end{abstract}

\section{Key words: Lupinus perennis, L. polyphyllus}

\section{Introduction}

NZMerino Ltd has a Primary Growth Partnership from the New Zealand Government. One aim of this programme was to increase the on-farm production of merino wool from high country farms. To achieve this, the Lincoln University dryland pastures group were engaged to jointly develop a research programme to identify pasture legumes that could be used in this environment. The expansion of the area of lucerne planted was identified as an obvious option for more wool production. As a consequence, rotational grazing of merino ewes and lambs on lucerne was successfully introduced and demonstrated at Bog Roy Station (Anderson et al. 2014). The animal performance figures have shown the benefits of higher lambing percentages and survival and greater herbage growth off the flat land, which has improved the adjacent hill country production. As a consequence, the expansion of lucerne planting is ongoing (Stevens et al. 2012) as farmers recognise the benefits of direct feeding in addition to its traditional role as a conserved feed for managing their 90-120 day winter.

However, lucerne is unsuitable for many regions of the high country where low $\mathrm{pH}$ and high $(>3.0 \mathrm{mg} /$ $\mathrm{kg}$ ) available aluminium in soils severely restrict its root growth and nodulation. Overcoming this with lime and fertiliser is possible (Kearney et al. 2010) but can be uneconomic or difficult where aluminium is present throughout the soil profile (Moir \& Moot 2014). Therefore, additional perennial legume species are required to provide the benefits of increased forage quality, nitrogen fixation and higher yields than the resident pastures. A long term grazing trial at Mt John, Tekapo, and observations from local roadsides indicate perennial lupins (Lupinus polyphyllus) survive the climate and have provided an ongoing source of feed over 30 years. It has been successful in trial plots and is adapted to low $\mathrm{pH}$ soils and higher rainfall nearer the Southern Alps (Scott 2008). However, there has been little commercial sowing of perennial lupins in the high country. This research was developed to enhance the potential of perennial lupins as a viable forage for the high country. The animal performance of merino sheep grazing lupins was quantified on-farm (Black et al. 2014) using the only commercially grown block of lupins in the district. At the same time, their ability to colonise a wide range of environments was confirmed along with their successful symbiosis with resident rhizobia populations (Ryan-Salter et al. 2014). Similar to many commercially successful pasture legumes, the perennial lupins do colonise open space and, while this is a useful agronomic feature, it can be a problem for the conservation estate (Department of Conservation 2014).

To complement these investigations, a more intensive agronomic research programme was established at Glenmore Station, Lake Tekapo. The site is typical of many within the region that are dominated by browntop (Agrostis capillaris) or sweet vernal (Anthoxanthum odoratum) and produce a minimal amount of quality spring herbage for grazing. The site also contained Kentucky bluegrass (Poa pratensis), a tough, sodforming grass, of little agronomic value. The aim was 
to generate guidelines for perennial lupin agronomy including sowing rate and early grazing management. The recommended preparation in this environment is to utilise cereal greenfeeds, such as ryecorn (Secale cereale), for 2-3 years to assist in the breakdown of the browntop thatch (Anderson et al. 2014). This is followed by permanent pasture, lupins or lucerne. However, in this research we aimed to determine whether a perennial pasture based around lupins could be established straight out of the resident vegetation, following guidelines from Kearney et al. (2010). The second aim was to determine the rate of lupin seed required to achieve this.

\section{Materials and Methods Site and preparation}

The experiment was established at Glenmore Station, Lake Tekapo, $\left(43.9028^{\circ} \mathrm{S} 170.4716^{\circ} \mathrm{E} ; 725 \mathrm{~m}\right.$ a.s.l.). Soil $\mathrm{pH}$ was 5.0 and exchangeable aluminium was $5.0 \mathrm{mg} / \mathrm{kg}$ (Moir \& Moot 2014). A $30 \times 90 \mathrm{~m}$ block of resident pasture was sprayed with glyphosate herbicide (3.6 kg a.i./ha) in March 2012, then the residual herbage was burnt in April. Lime at $3 \mathrm{t} / \mathrm{ha}$ was applied on 17 May to half of the area $(15 \times 90 \mathrm{~m})$. The area was then fallowed through winter and spring before a further glyphosate application of $1.44 \mathrm{~kg}$ a.i./ha was applied on 4 December 2012. A week later, the experiment was sown using a "Flexiseeder" precision plot drill fitted with tine coulters. Fertiliser (100 kg/ha Cropmaster 20; $\mathrm{N}: \mathrm{P}: \mathrm{K}: \mathrm{S}, 19.3: 10: 0: 12.5)$ was applied simultaneously via the drill's coulters from a separate fertiliser box. No additional fertiliser was applied during the experiment. The site, on old glacial moraine deposits, was variable as inferred from the variation in botanical composition of the resident vegetation. Block 1 (see Experimental design below) was dominated by a moderately heavy browntop cover prior to herbicide treatment, indicating a deeper soil, and Block 3 was partially located on a slight rise with thinner stony soils previously covered with a high proportion of annual adventive legumes. Block 2 was intermediate.

\section{The lupins}

The lupin seed was supplied via Rosevear \& Co. Ltd, Ashburton, from a local commercial grower. The two lupin varieties used here are colloquially referred to as "blue" and "Russell" lupin by the seed supplier. This blue, perennial lupin, is not to be confused with the annual "blue lupin" (L. angustifolius) which is a commonly planted forage lupin. The "Russell" lupin seeds were mostly derived from collections of roadside populations of the multi-coloured horticultural lupin hybrid L. polyphyllus $\times$ L. arboreous and likely to include genetic material from other lupin species (Edward 2003).

\section{Experimental design}

The area was divided across its $90 \mathrm{~m}$ axis into three 30 $\times 30 \mathrm{~m}$ blocks (replications). The $3 \mathrm{t} / \mathrm{ha}$ vs zero lime treatment formed the main plots within each block though not randomised. Each block was divided into six subplots of $4.2 \times 30 \mathrm{~m}$, traversing the full $30 \mathrm{~m}$ width of the \pm lime strips. Within these, the lupin sowing rate (LSR) was $2,4,8,12,16$ or $32 \mathrm{~kg} / \mathrm{ha}$ along with $2 \mathrm{~kg} /$ ha of 'Vision' cocksfoot (Dactylis glomerata). Each subplot was also split along its length to form $2.5 \times 30$ $\mathrm{m}$ sub-sub-plots (one $2.1 \mathrm{~m}$ drill width of either blue or Russell lupin plus a narrow unsown border). A splitsplit-plot analysis of variance consisting of blocks (3), main-plots $( \pm$ lime), sub-plots $(\mathrm{LSR}=6)$ and subsub-plot (variety $=2$ ) was used to assess the statistical significance of the applied treatments. The design was fully randomised at the sub-plot and sub-sub-plot levels but not at the main plot (lime) level.

\section{Measurements}

Germination (\%) of the unscarified lupin seed at 7 days was $65 \%$ for blue lupin and 55\% for Russell lupin but seeding rates were not adjusted for this. Germination, originally tested in September 2011 by Seedlab (no. $112365 \& 112366$ ) was $80 \%$ at 30 days for blue lupin and $67 \%$ for Russell lupin.

Field measurements on six dates included: 1) plant emergence at 6 weeks after sowing (24 January 2013); 2) lupin establishment as determined by plants with three or more fully expanded leaves, dry matter (DM) yield using a capacitance probe and visual sward composition on 7 March 2013; 3) machine harvest for DM yield and botanical composition on 17 April 2013; 4) capacitance probe measurement for relative yield at 24 October 2013; 5) machine harvest for total spring DM yield and sward composition on 2 December 2013 followed by grazing and DM assessment of the residual; and 6) hand harvest for DM yield composition and plant population on 24 March 2014 to assess the summer recovery after grazing and complete the estimate of annual DM yield. In addition, 32 plants were randomly selected and individually marked across the experimental area in April 2013 and then scored to assess winter survival in September 2013.

Plots were grazed in common with the total 2 ha paddock on three occasions: mid-June 2013 with 700 ewes for two days; early December 2013 with 1200 merino two-tooths for four days following the yield assessment; late March 2014 after the final yield determination for the 2013/14 season.

Temperature and rainfall were recorded on site and compared with NIWA long term records. Temperatures were near the 30 year normal (Figure 1). Monthly rainfall was typically variable. An $80 \mathrm{~mm}$ rain event at the beginning of January 2013, 4 weeks after 


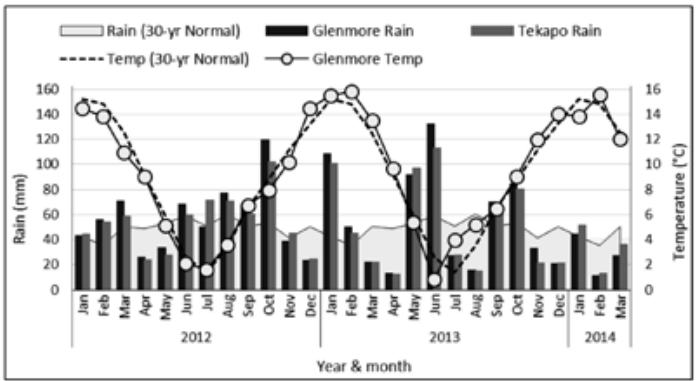

Figure 1 Rainfall and air temperature recorded on site at Glenmore. Current rainfall and 30-year normal rain and mean temperatures from Lake Tekapo EWS climate station (NIWA CliFlo data 2014) are included.

sowing, was ideal for emergence and establishment. This rain and the conserved moisture from the spring fallow allowed consistent growth through to autumn 2013. Heavy rain and snow in June 2013 followed by sufficient rain in July-September meant soils started spring at field capacity. Rainfall during spring of the second year was slightly higher than normal but the summer and early autumn were drier which restricted pasture growth after the December grazing.

\section{Results}

\section{Plant population}

The lupin emergence, January 2013, and establishment, March 2013 (Year 1) were affected by sowing rate $\left(\mathrm{P}<0.001\right.$; Figure 2a). Over 40 seedlings $/ \mathrm{m}^{2}$ emerged in January at the highest sowing rate, and plant numbers were comparatively stable over the next two months. There were at least 12 plants $/ \mathrm{m}^{2}$ in plots with a sowing rate $\geq 8 \mathrm{~kg} / \mathrm{ha}$ and a difference between lupin varieties $(\mathrm{P}=0.002)$ at the end of the establishment period in March 2013 (Figure 2b). However, by March 2014 (Year 2) lupin plant numbers had decreased to below 12 plants $/ \mathrm{m}^{2}$ across all sowing rates (Figure 2c) and below 9 plants $/ \mathrm{m}^{2}$ at sowing rates $<12 \mathrm{~kg} / \mathrm{ha}$. Of the 32 marked plants from the previous autumn, none had died or appeared weakened as a result of the autumn grazing or winter frosts when viewed in September 2013 (Year 2). The mean cocksfoot population in March 2014 was only 3.6 plants $/ \mathrm{m}^{2}$ but plants were vigorous. Despite a lupin sowing rate effect $(\mathrm{P}=0.013)$ on the cocksfoot population, there was no apparent trend over the six sowing rates. However, the mean cocksfoot populations were 4.3 and 2.8 plants $/ \mathrm{m}^{2}(\mathrm{P}<0.001)$ with $3 \mathrm{t}$ lime/ha and no lime, respectively, and 3.1 and 4.0 plants $/ \mathrm{m}^{2}$ $(\mathrm{P}=0.024)$ when sown with blue and Russell lupins, respectively.

\section{Year 1, Yield from sowing to first harvest}

The capacitance probe measurements on 7 March 2013 and visual estimates of plant cover showed the same pattern as the mechanical harvest on 18 April 2013. Yield increased with the lupin sowing rate to over $5 \mathrm{t}$ $\mathrm{DM} / \mathrm{ha}$ at $32 \mathrm{~kg}$ seed/ha (Figure $3 \mathrm{a} ; \mathrm{P}<0.001$ ). There was a dominance of lupin herbage in all treatments with $<5 \%$ cocksfoot and other components. Sowing rates between 8 and $16 \mathrm{~kg} /$ ha produced $>2 \mathrm{t} \mathrm{DM} / \mathrm{ha}$. Blue lupin yielded slightly more than Russell lupin (Figure $3 \mathrm{~b} ; \mathrm{P}=0.027$ ), possibly reflecting the $10 \%$ higher germination and emergence. Bare ground decreased from 64 to $7 \%$ with the increase in sowing rates $(\mathrm{P}<0.001)$. It decreased from 43 to $27 \%$ overall with liming $(\mathrm{P}=0.019)$. There was $37 \%$ bare ground with Russell lupin and $33 \%$ with blue lupin ( $\mathrm{P}=0.008$ ). Re-established resident species were more prevalent at the lower sowing rates.

By late May 2013 before the mid-June grazing many lupin plants had flowered but had not set seed, and older leaves were senescing.

\section{Year 2, Annual yield (December 2013 and March 2014)}

The mean annual DM yield across all treatments for Year 2 (sum of harvests on 3 December 2013 and 24 March 2014) was 11.0 t/ha (Figure 4a) but differed with sowing rate. Lupins sown at $2 \mathrm{~kg} /$ ha produced $6-8 \mathrm{t}$

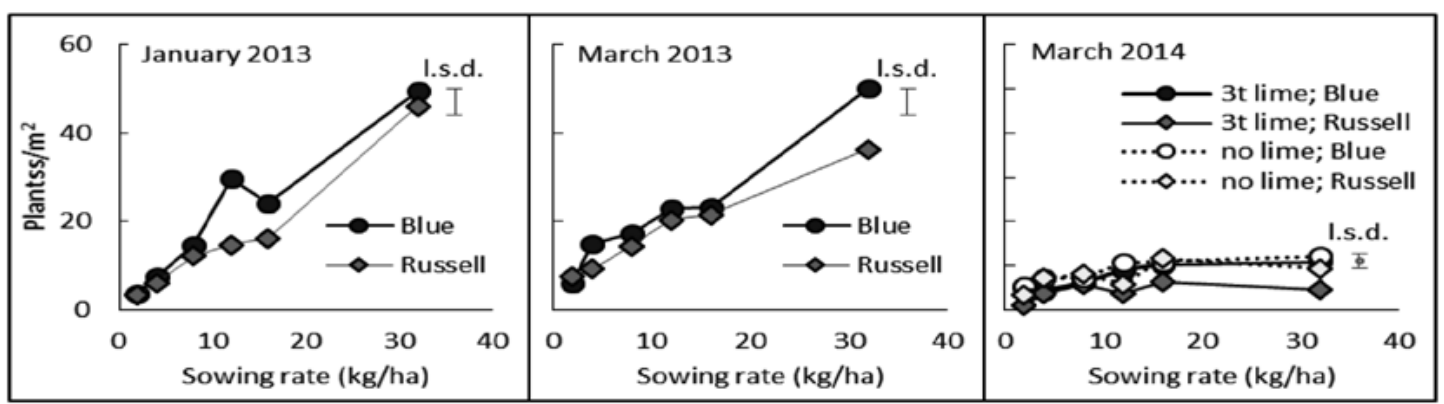

Figure 2 Plant population of perennial lupins at 6 sowing rates on 11 December 2012, during the establishment phase in January and March 2013 (Year 1), and at 24 March 2014 (Year 2), in response to \pm lime, lupin sowing rate and lupin variety at Glenmore Station. There was a lupinxsowing rate interaction in Year $1(P<0.01)$ and both limexlupin and sowing ratexlupin interactions in Year 2. Least significant differences between means (I.s.d.) are shown. 


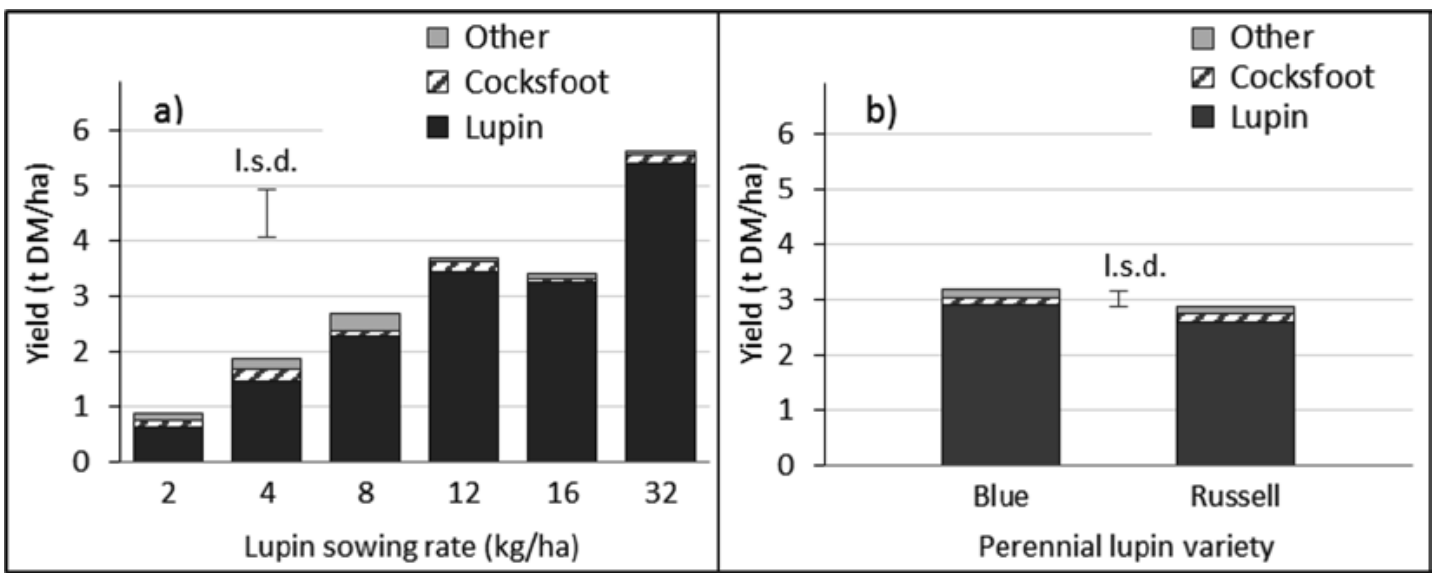

Figure 3 Total dry matter (DM) yield of lupin/cocksfoot pasture on 18 April 2013 from sowing on 11 December 2012 in response to a) sowing rate and b) lupin variety. Least significant differences between means (I.s.d.) are shown.

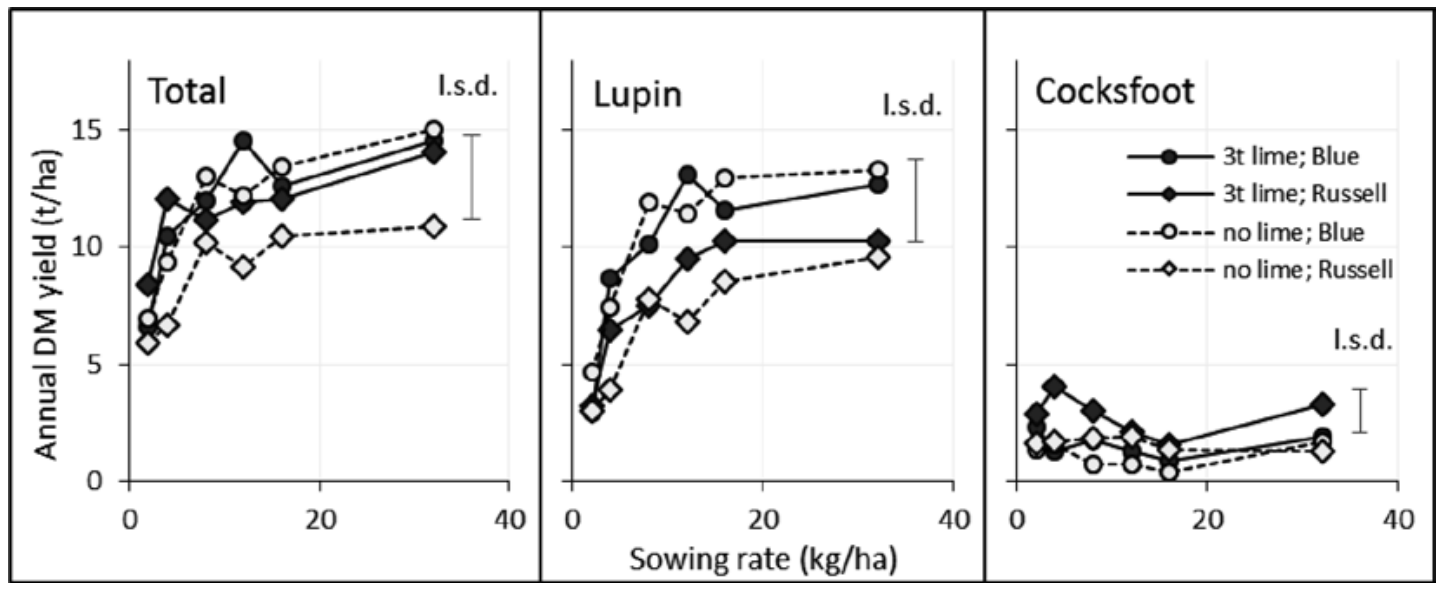

Figure 4 Mean annual dry matter (DM) yield in Year 2 for pastures at Glenmore Station sown with six rates of either blue or Russell lupin. Least significant differences (I.s.d.) are shown.

$\mathrm{DM} / \mathrm{ha}$ compared with $11-15 \mathrm{t} \mathrm{DM} / \mathrm{ha}$ at $8 \mathrm{~kg} / \mathrm{ha}$ or higher for all but the unlimed Russell lupin pasture $(\mathrm{P}<0.022$ for the LSR $\times$ lupin variety interaction $)$. Overall, the lupin component was $80 \%$ of the annual yield (Figure $4 \mathrm{~b}$ ) and cocksfoot 16\% (Figure 4c). The lupin yield (Figure $4 \mathrm{~b}$ ) increased sharply with sowing rates up to $8 \mathrm{~kg} /$ ha but showed small absolute, but not significant, increases at the higher sowing rates. Blue lupin was more responsive than Russell lupin. The proportion of cocksfoot (Figure 4c) was greater when sown with Russell than blue lupin $(\mathrm{P}<0.001)$.

Over $80 \%$ of the total Year 2 yield was from the December 2013 harvest which averaged $9.1 \mathrm{t} \mathrm{DM} / \mathrm{ha}$. The blue lupin contributed $>90 \%$ of the December yield at sowing rates greater than $4 \mathrm{~kg} / \mathrm{ha}$ while cocksfoot contributed $10-20 \%$ at the lowest sowing rate but $<10 \%$ at sowing rates above $8 \mathrm{~kg} / \mathrm{h}$. There was little bare ground at this stage. Regenerating resident species, mostly Kentucky bluegrass, browntop and sweet vernal invaded the lower sowing rate plots. Lodging, defined as more than $20 \%$ of lupin plants toppled, was prevalent in blue lupin at sowing rates $\geq 16 \mathrm{~kg} / \mathrm{ha}$, but not for Russell lupin. This occurred in response to gale force wind gusts $(60-98 \mathrm{~km} / \mathrm{h})$ from the NNE coupled with light rain during the weekend prior to the spring harvest (NIWA CliFlo data from Lake Tekapo EWS). The flower stalks had just reached their full height and were likely to be at their most susceptible stage for lodging. In the highest sowing rates, individual lupin plants were relatively spindly with fewer but mostly long-petioled leaves.

For the March 2014 harvest, the mean cocksfoot yield $(1.0 \mathrm{t} \mathrm{DM} / \mathrm{ha})$ accounted for $53 \%$ of the total harvest and lupin contributed $42 \%$. The only treatment effect at this harvest was that blue lupin yielded $0.97 \mathrm{t} \mathrm{DM} / \mathrm{ha}$ and Russell $0.64 \mathrm{t} \mathrm{DM} / \mathrm{ha}(\mathrm{P}<0.001)$. There was up to $60 \%$ bare ground at the lowest sowing rate and $40 \%$ at the highest $(\mathrm{P}<0.001)$. The mean bare ground was $49 \%$ for blue lupin and 55\% for Russell lupin ( $\mathrm{P}=0.021)$. 


\section{Grazing and utilisation of the spring growth.}

Following the 3 December 2013 yield harvest, the introduced sheep had no previous experience grazing lupins. They initially ate the clover and lucerne from surrounding experiments and then moved into the lupin experiment (Will Murray pers.comm.). Here they consumed the flowers and green leaf first. After two days there was little green leaf left on the lupin, only denuded flower stalks and a few leaf petioles remained. Flower stalks, up to one meter tall before grazing, were reduced to less than half their height or broken and trampled. Flower stalks of cocksfoot also remained, but green leaf was removed to leave only pseudo stems at the base. The ratio of post-graze DM yield to the pregraze DM yield was used as a proxy for utilisation. The mean utilisation of the lupin-cocksfoot pasture was $64 \%$ for $3 \mathrm{t} \mathrm{lime} / \mathrm{ha}$ and $52 \%$ for no lime $(\mathrm{P}<0.002)$. Utilisation of the lupin alone was $71 \%$ and $49 \%$ for the $3 \mathrm{t}$ lime/ha and no lime, respectively $(\mathrm{P}<0.001)$. Separation of the lupin plant parts from 20 of the pregrazed samples showed $45 \%$ of the lupin DM was from the flowers, green leaf lamina and pods and $49 \%$ from the flower stalks and leaf petioles.

\section{Discussion}

Successful establishment of perennial lupin based pastures was achieved through the "double spray" technique with glyphosate in autumn, followed by a burn, and then the second glyphosate spray immediately pre-planting the following spring. This method of preparation effectively reduced the competition from the thatch of browntop and Kentucky bluegrass that dominated the site. Importantly for the success of the "double spray", autumn rainfall (Figure 1) ensured the grasses had sufficient green leaf to take up the chemical. This is then translocated to stolons and rhizomes to increase the effectiveness of control. The resultant dead material was able to be burnt and removed before the second, spring application killed the regenerating grasses and other weeds. A similar approach was advocated by Kearney et al. (2010) to successfully establish lucerne in Central Otago out of resident vegetation. In both examples minimal seedbed preparation was used to shorten the process of establishment. However, caution should be exercised when advocating this establishment approach. In a dry autumn, the herbicide application may be ineffective and the resident vegetation may reinvade more quickly. In these low productivity environments, where pasture establishment is a comparatively expensive exercise, the more traditional approach of 2-3 years of cereal greenfeed carries less risk (Anderson et al. 2014). The cereal greenfeed has the added advantage of providing winter feed, while heavy mob stocking assists the mechanical breakdown of the browntop thatch. It also remains to be seen how long these newly established pastures remain free of reinvading weed species, and this will be monitored for the next 2 years.

It was apparent by the end of the experiment that the different sowing rates of perennial lupins had affected the botanical composition of the pastures established. For both blue and Russell lupins a sowing rate of $8 \mathrm{~kg} / \mathrm{ha}$ is recommended. At this rate there was an adequate population of plants established, and these survived to the first autumn grazing and into year two. We must emphasise that there was favourable rainfall for the establishment phase which allowed this grazing. In a more normal, drier, summer (Figure 1) the lupins may need a laxer grazing management in their first year or no grazing at all. A key component of the current success was the fallow in spring to conserve moisture which ensured emergence. Without the follow-up summer rain, growth in this establishment season would be reduced. The highest sowing rates used here were insurance in case we experienced a dry summer year. The lower sowing rates left more bare ground available for cocksfoot establishment, but also added the threat of reinvasion of the less desirable resident grasses and broadleaf weeds. The yield from all sowing rates showed the potential for lupins to increase the amount of herbage grown. The Year 1 yield of ca. $3 \mathrm{tha}^{-1}$ from sowing to mid-April consisted of plants that had produced a cluster of long-petioled leaves from a developing crown with some flower stalks. It is likely that the partitioning of growth of lupins follows that of other perennial legumes, such as lucerne, where the emphasis is on below-ground establishment in the first year (Thomas 2003). Russell lupin seedlings from a nearby experiment sown at the same time as the present experiment and dug up in May 2013 had mean root, crown and shoot DM of 37.0, 7.32 and $41.7 \mathrm{~g}$, respectively (Moot 2013). This first summer allowed sufficient growth to occur for plants to cope with a light grazing in autumn, survive the winter die back and regrow at similar numbers in spring. The yield in Year 2 was over $10 \mathrm{t} \mathrm{DM} / \mathrm{ha}$ for crops sown with $8 \mathrm{~kg} / \mathrm{ha}$ or more and this was predominantly produced by lupin in spring (Figure 4). The timing of this feed has been shown to suit ewes with lambs in this environment (Black et al. 2014). The height of the lupin plants provides additional ecological service of shelter and ground cover. The highest lupin sowing rates also showed weed suppression but the lupins suffered from the intense inter-plant competition.

The use of cocksfoot as a companion species was successful when included at a sowing rate of $2 \mathrm{~kg} / \mathrm{ha}$. The cocksfoot benefitted more than the lupins from the 
addition of $3 \mathrm{t} / \mathrm{ha}$ of lime, and made up around $20 \%$ of the yield in both years at the lupin sowing rate of $8 \mathrm{~kg} / \mathrm{ha}$ or less. The aim of the cocksfoot as a companion species was to provide ground cover amongst the distinct lupin plants. The grass is then able to grow with the nitrogen provided via the lupin grazing (Black et al. 2014). The utilisation of the lupin/cocksfoot pasture was enhanced by the addition of lime. However, the lupin growth was not enhanced by the lime, which suggests the use of lime would be advantageous to the quantity and quality of companion species and maximise the feed on offer. Lupins are known to be unpalatable to stock because of the presence of alkaloids in all above ground parts. David Scott (pers. comm.) has assessed the lupins on site and found the two lupin varieties had similar alkaloid content. While not the first choice for the sheep during the December grazing, once started, the sheep quickly devoured the flowers and leaves which are the most nutritious feed (Black et al. 2014). Grazing the lupin/cocksfoot stand earlier in the spring may allow the cocksfoot to be grazed preferentially before its reproductive stems appear, thus avoiding over-grazing the lupin if stock are removed while some lupin leaves still remain. The earlier and more frequent grazing of the cocksfoot also reduces its unpalatable reproductive stem growth and promotes a more uniform less clumped sward.

The significant drop in plant numbers of lupins by March 2014 may represent self-thinning, but is also the consequence of the hard grazing in December. The plants that remained had become dominant and a population of more than about 10 plants $/ \mathrm{m}^{2}$ would seem unnecessary to maximise lupin yield by this point. It remains to be seen whether the population will persist, but previous research (Scott 2008) suggests longevity. Should the population be diminished by the grazing, it may be possible to thicken up a stand by allowing some of the flowers to develop pods and drop seeds. How successful this is in this environment, where a resident seed bank of weeds is apparent, remains to be measured. The persistence of blue versus Russell lupins also remains to be seen. The $10 \%$ higher germination rate for blue lupin appears to have given an initial advantage at sowing and establishment (Figure 2). This may have benefitted its yield in Year 2 (Figure 4b) but both varieties appear to have established an adequate plant population to maintain production into Year 3 . The vigorous growth of this species in the presence of high aluminium (Moir \& Moot 2014) in the soil highlights its potential to provide a nitrogen fixing perennial legume in an environment that is unsuitable for lucerne.

\section{Conclusions}

Perennial lupins were successfully established into the resident vegetation at Glenmore Station. These first two years' results show a thriving stand with an expanding cocksfoot population that will significantly out-yield the resident browntop dominated pasture. A sowing rate of about $8 \mathrm{~kg} / \mathrm{ha}$ was adequate for plant establishment of both Russell and blue lupins, and the application of lime aided the cocksfoot growth. In these highly acidic soils, that have aluminium levels that are toxic to lucerne, the lupins have provided a viable perennial legume option.

Sow lupins at $8 \mathrm{~kg} / \mathrm{ha}$, or lower if germination is $>80 \%$. Use higher rates where canopy dominance is necessary to control re-invasion by resident species. Use lower rates where moisture is reliable, weed control and seed bed preparation are maximised and when desirable companion species are sown with the lupin. If cost effective, use lime to benefit the companion species and improve pasture quality for stock.

\section{ACKNOWLEDGEMENTS}

NZMerino Ltd and Ministry of Primary Industries provided funding. We thank Will and Emily Murray of Glenmore station for on-site and accommodation assistance, Denis Fastier, Simons Hill Station, for on-going field co-ordination. Anna Mills and Simon Hodge, Lincoln University, assisted with statistical analysis and students and technical staff assisted in the field and laboratory.

\section{REFERENCES}

Anderson, D.; Anderson, L.; Moot, D.J.; Ogle, G.I. 2014. Integrating lucerne (Medicago sativa L.) into a high country Merino system. Proceedings of the New Zealand Grassland Association 76: 29-34.

Black, A.D.; Loxton, G.; Ryan-Salter, T.P.; Moot, D.J. 2014. Sheep performance on perennial lupins over three years at Sawdon Station, Tekapo. Proceedings of the New Zealand Grassland Association 76: 3539.

Department of Conservation 2014. Weed: Russell lupin. http://www.doc.govt.nz/ conservation/threats-and-impacts/weeds/commonweeds-in-new-zealand/russell-lupin/. Date unspecified. Accessed July 2014.

Edward, P. 2003. The Russell lupin story. National Council for the Conservation of Plants and Gardens. 48 pp. (ISBN 0-9544579-0-0)

Kearney, J.K.; Moot, D.J.; Pollock, K.M. 2010. Onfarm comparisons of pasture production in relation to rainfall in Central Otago. Proceedings of the New Zealand Grassland Association 72: 121-126. 
Moir, J.L.; Moot, D.J. 2014. Medium-term soil pH and exchangeable aluminium response to liming at three high country locations. Proceedings of the New Zealand Grassland Association 76: 41-45.

Moot, D.J. 2013. Forage establishment and management in the high country of New Zealand. Progress Report to New Zealand Merino Company Ltd. 115 pp.

NIWA CliFlo Database. 2014. http://cliflo.niwa.co.nz/. Accessed June 2014.

Ryan-Salter T. P.; Black, A.D.; Moot, D.J. 2014. Identification and effectiveness of rhizobial strains that nodulate Lupinus polyphyllus. Proceedings of the New Zealand Grassland Association 76: 61-65.
Scott, D. 2008. Sustainability of high-country pastures under contrasting development inputs. Proceedings of the New Zealand Grassland Association 70: 1923.

Stevens D.R.; Thompson, B.R.; Carruthers, A.; Wall, A.J.; Casey, M.J.; Phiskie, R.; Young, P; Moot, D.J. 2012. Understanding the role of spring grazing of lucerne in the Central Otago environment. Proceedings of the New Zealand Grassland Association 74: 69-76.

Thomas, R.G. 2003. Comparative growth forms of dryland forage legumes. In: Moot, D.J. Ed. Legumes for dryland pastures. New Zealand Grassland Association, Research and Practice Series 11:19-25. 